\title{
DISCURSO DOCENTE SOBRE A LÍNGUA INGLESA: CONCEPÇÕES SOBRE SI, O ENSINO-APRENDIZAGEM, A DOCÊNCIA E A LINGUAGEM
}

\author{
(Teacher's discourse about English language: conceptions about the self, learning-teaching, \\ teaching profession and language)
}

\author{
Gilberto Alves Araújo ${ }^{1}$ \\ (University of the Witwatersrand, University of Mannheim \& Universidade Federal do Pará)
}

\begin{abstract}
RESUMO
Este estudo pretende analisar representações discursivas nos enunciados de professores acerca deles mesmos, do exercício da docência, do ensino-aprendizagem de língua inglesa (LI) e sua inserção na escola. Assim, por meio de um estudo de caso com professores da rede pública de ensino do interior de Tocantins, os quais foram acompanhados em seu trabalho cotidiano durante 10 meses e entrevistados em diversas ocasiões, este artigo também discute o funcionamento situado das concepções de esquecimento, assujeitamento e formações ideológica e discursiva, originárias da Análise do Discurso Francesa que constitui o arcabouço teóricometodológico deste trabalho. Desse modo, investigações aqui apresentadas apontam que prestígio e status sociais frequentemente atribuídos à LI cedem maior espaço à ideia de batalha/sofrimento, enquanto os sentimentos de conquista, autorrealização e ganhos financeiros são silenciados. Professores encontram em uma suposta superioridade intelectual, no utilitarismo linguístico e no sistema econômico as razões para o ensino de LI. Não obstante, a imagem de agente de resistência e a noção implícita de símbolo sacrificial ainda emergem nas construções discursivas acerca de si.
\end{abstract}

Palavras-chave: Discurso. Lingua inglesa. Ensino-aprendizagem. Professor. Tocantins.

\section{ABSTRACT}

This work intends to analyse discursive representations within teachers' enunciates regarding themselves, the exercise of their teaching role, as well as English language (EL) teaching-learning and its insertion in school. Thus, through a case study with teachers from public schools in Tocantins countryside, who were observed in their everyday work over a period of 10 months and interviewed in several occasions, this paper also discusses the situated functioning of conceptions such as forgetting, subjecting, ideological and discursive formations, which stem from French Discourse Analysis, the theoretical-methodological framework of this study. Accordingly, investigations presented in here point out that prestige and social status, often assigned to EL, offer significant space to the ideas of struggle/suffering, whereas the sense of accomplishment, self-fulfilment and financial gains are silenced. Teachers find the reasons for EL teaching through a presumed intellectual superiority, a linguistic utilitarianism and the economic system. Notwithstanding, the image of resistance agent and the implicit notion of sacrificial symbol still emerge in the discursive constructions about the self.

Keywords: Discourse. English language. Teaching-learning. Teacher. Tocantins.

Recebido em: junho 2019

Aceito em: dezembro 2019

DOI: $\underline{10.26512 / \text { les.v20i2.25374 }}$

\footnotetext{
${ }^{1}$ Doutorando na School of Literature, Language and Media, University of the Witwatersrand (África do Sul) com período sanduíche no Department of Linguistics, University of Mannheim (Alemanha). Professor Assistente A2 (afastado para doutoramento) da Faculdade de Letras, Departamento de Língua Inglesa, Universidade Federal do Pará (Brasil), e-mail: gilbertoa.araujo@yahoo.com.br.
} 


\section{INTRODUÇÃO}

Este artigo pretende discutir representações discursivas construídas por professores acerca de si mesmos, da docência, do ensino-aprendizagem de idiomas e da disciplina de língua inglesa (LI) na escola. Para tanto, recorremos às concepções teóricas da Análise do Discurso, notadamente às noções de esquecimento, assujeitamento, formações ideológica e discursiva (PÊCHEUX, 1995; 1997; 2006), e também à metodologia aduzida por Orlandi (1998, 1999).

Ao empregar esses instrumentos teórico-metodológicos, cremos ser possível revelar como formações, estratégias e processos discursivos realizam o trabalho ideológico de moldar o discurso dos professores dentro de uma lógica colonial-capitalista, compelindo indivíduos, redirecionando a disciplina escolar e conformando sujeitos a posições bastante específicas, contraditórias e incomuns. Além disso, será possível vislumbrar como a presença ou a ausência do neoliberalismo e da democracia-liberdade é capaz de interferir nos efeitos e potenciais uma da outra através do discurso docente acerca do currículo de LI, cuja implementação parece bastante ineficiente neste caso.

Nesse sentido, a falha dos sistemas educacionais (estaduais públicos) em relação ao ensino de língua estrangeira não é uma exclusividade do Brasil. Mesmo em países "ricos" e "desenvolvidos" como os Estados Unidos, o déficit educacional em letramento e numeramento tem chamado a atenção de pesquisadores de diversas áreas científicas ao redor do globo. Nosso estudo de caso envolvendo os professores de Tocantins, estado no norte do Brasil, certamente não é uma exceção a essa dinâmica. Diversos resultados do ENEM² (Exame Nacional do Ensino Médio) sugerem quão problemáticas as performances de ensino-aprendizagem têm se tornado no sistema educacional estadual selecionado.

Os sintomáticos números disponibilizados pelo Ministério da Educação a respeito do ensino público Tocantinense provocaram inúmeros debates entre os legisladores estaduais, professores, sindicatos, estudantes e seus familiares durante os anos de 2007 e 2008. Desse momento em diante, ao invés de refletir não apenas sobre os problemas materiais, mas também os instrumentais e menos tangíveis que possibilitaram o fracasso do sistema, oficiais do governo começaram a reelaborar planos de carreira docente, a propor aumento salarial (que encontrava-se então entre os mais baixos dos estados da federação), na esperança de apascentar a opinião pública e possivelmente assegurar votos nas eleições seguintes - uma prática bastante frequente na política populista. No entanto, anos depois, em 2010, o sistema educacional tocantinense continuava ocupando uma das últimas posições no ranking nacional, causando reações comparáveis ao que se notou nos anos anteriores. Essa realidade

\footnotetext{
${ }^{2}$ Em 2005 e 2006 o Tocantins ocupou a 26a (entre 27 estados) e a última posição respectivamente (Brasil, 2007). Em 2007 o estado obteve a última posição (G1-Notícias, 2008). Em 2008 e 2009 esteve em último e antepenúltimo lugar (G1-Notícias, 2010).
} 
continuou a se repetir nos anos seguintes, incluindo o ano passado, 2018, em que o Tocantins ocupou a $22^{a}$ posição entre 27 unidades da federação, mas agora sem maior alvoroço, seja na comunidade acadêmica ou entre os membros da classe política local (FSP, 2019).

À luz desses fatos, nosso trabalho procura discutir como representações discursivas de professores pode nos ajudar a entender não apenas o efeito dos discursos coloniais-capitalistas de exaltação do inglês, bem como seus fundamentos ideológicos e metodológicos, e da mesma forma suas tendências em relação a práticas mais ou menos frutíferas. Em outras palavras, exploramos os possíveis fatores latentes, instrumentais ou indiretos que exercem influência sobre o relativo insucesso do ensino de LI no discurso docente, contrastando o último com os extremos do capitalismo neoliberal de um lado, e a justiça democrática e progressista de outro. Como veremos, independente do que os políticos locais possam ter dito à época dos primeiros resultados alarmantes, condições materiais são componentes subsidiários às construções teórico-metodológicas e ideológicas, que - se voltadas contra o gerenciamento mais democrático, aberto e participativo do ensino-aprendizagem dificilmente permitirão que estudantes e professores contemplem o progresso intelectual e as conquistas coletivas para além de salários e planos de carreira, prédios ou salas de aula adequadas.

Este artigo se divide em três seções. A $1^{\text {a }}$ apresenta nossas assunções teóricas e algumas perspectivas metodológicas. A $2^{\mathrm{a}}$ analisa e discute o discurso docente acerca de si, da docência, bem como a respeito do ensino-aprendizagem em geral e da LI como uma disciplina. Por fim, sintetizamos nossa discussão oferecendo abordagens gerais para uma futura educação linguística.

\section{Pressupostos teóricos e Metodológicos}

\subsection{Conceitos da Análise do Discurso Francesa}

Neste trabalho, empregamos os conceitos de polissemia, paráfrase, metáfora e antecipação, bem como as noções de Formação Discursiva (FD), esquecimento (número um/dois), Formação Ideológica (FI), e assujeitamento, que por sua vez se subdivide em processos de identificação, desidentificação e contraidentificação - itens explanados a seguir a partir de seus pontos-chave.

Antes de tudo, é preciso notar que de um ponto de vista fenomenológico, a Análise do Discurso de Pêcheux é a mais adequada para ler discursos com essa filigrana de natureza mais voltada às nuances ideológicas e de formação socio-histórico, que é o que almejamos aqui. Ademais, diferentemente de outros tipos de Análise do Discurso, a perspectiva Pecheutiana estabelece o materialismo histórico como teoria das formações sociais e suas transformações. Semelhantemente, Pêcheux e Orlandi se firmam sobre a linguística majoritariamente como uma teoria dos mecanismos sintáticos/sintagmáticos e dos processos de enunciação, não se tornando excessivamente dependente 
de dados linguísticos tangíveis. Além disso, é a partir de ambos os teóricos que uma teoria do discurso é tratada como uma teoria da determinação histórica dos processos semânticos.

Para o pesquisador isso significa que a semântica é a dimensão essencial dentro da linguística. A semântica, portanto, aproxima a filosofia da experiência humana ao materialismo histórico. Dito de outro modo, se os processos discursivos são considerados a fonte de produção dos efeitos de sentido, a língua é o espaço tangível em que esses efeitos são concretizados. Evidentemente, do ponto de vista Pecheutiano, a língua susterá sua relativa autonomia perante as diferenças e embates entre grupos e alianças sociais, que por sua vez apropriar-se-ão, sempre diferentemente, da língua. Portanto, outra contribuição não-proposital desse artigo pode ser a exploração dos graus de autonomia da língua em face dos conflitos ideológicos no discurso.

Pois bem, a saber, Pêcheux (1995, p. 160) concebe FD como um projeto de coesão e coerência, que sob certa conjuntura e estado de luta de classes, "determina o que pode e deve ser dito (articulado sob a forma de uma arenga, de um sermão, de um panfleto [...]). Por outro lado, o estudioso nota que a pretensa homogeneidade ou univocidade da FD seria, de fato, um simulacro, pois sua natureza essencial é heterogênea, considerando que a ideologia é constante interpeladora do sujeito, o que afeta/altera significativamente os discursos e suas condições de manifestação.

Intimamente ligados às FDs encontram-se dois processos essenciais à reprodução e circulação de discursos, duas espécies de esquecimento que interveem na constituição do sujeito, ou seja, em suas filiações a determinadas FDs. A $1^{\mathrm{a}}$ espécie ou tipo de esquecimento é inconsciente e ideológico, e permite ao sujeito fazer de si mesmo a fonte de tudo o que diz, denegando tudo o que não se insere na sua FD. A $2^{a}$ espécie ou tipo de esquecimento é anteconsciente ou quase consciente, e consiste no fato de que o sujeito, na seleção de dizeres, prestigia certas formas e procura eliminar outras. Por meio dessa operação, ele acredita na univocidade de sentido do seu dizer. Trata-se de uma peleja contra a heterogeneidade, e um anseio pela coerência e coesão do seu ser, e dizer-fazer.

Quanto à FI é preciso, primeiramente, notar que esta é composta de várias FDs. Essa relação somente é possível porque as FIs são superestruturas ainda mais abrangentes e, muitas vezes, sutis, capazes de direcionar não apenas as práticas discursivas, mas também seus sujeitos. Formalmente, as FIs podem ser entendidas como um agrupamento complexo de atitudes, práticas de significação e, por conseguinte, representações mais ou menos ligadas ao posicionamento de classes, que se encontram sempre em conflito com outra[s] (PÊCHEUX, 1997). Em última instância, a FI pode ser tomada como um conjunto de práticas modais de acessar, interpretar, experienciar o mundo, o princípio motor capaz de determinar/delinear embates entre classes sociais. Cada um desses conjuntos é também construído a partir da realidade e das relações que cada classe mantém com as outras, consigo, com a história e a linguagem, ao passo em que estes elementos a determinam. 
Nesse sentido, o assujeitamento é, em parte, fruto dos diversos processos de identificação, isto é, resultado do trabalho da ideologia em interpelar o indivíduo em sujeito, conforme apresentado adiante (modalidades de assujeitamento). Assim, diríamos que à medida que se constituem 'forma', os sujeitos vão se deslocando por posições que ocupam/projetam, regidos pelas forças que lhe são coercitivas e situacionais - daí forma-sujeito e posição discursiva (PÊCHEUX, 1995).

A posição-sujeito (sujeito enunciador), por sua vez, trata-se de uma plataforma relacional, um mapa imaginário através do qual é possível visualizar os lugares sociais que o sujeito vai assumindo no processo de mobilização discursiva ou assujeitamento (perante as FDs ou FIs) (PÊCHEUX, 1995). São essas conexões complexas e os efeitos de sentido engendrados nesse contexto de relação de forças ou dizeres que nos permitem supor quem "é" e o que faz esse sujeito.

Para Pêcheux (1995, p. 213-270) aquelas modalidades de assujeitamento são três. A primeira consiste na identificação dos saberes que caracterizam o sujeito universal com o pretenso indivíduo que se arraiga e se reconhece no interior de uma FD. Essa identificação é tão plena e eficaz que de dentro de suas posições o sujeito se enxerga como enunciador, como senhor de seu próprio dizer.

A segunda reflete um movimento de contraidentificação (resistência passiva) do sujeito enunciador contra o universal. Mediante a inquirição e a dúvida, a altercação, a revolta, a conjunção com outras FDs/FIs, o enunciador, embora não negue os conhecimentos do seu ser universal, passa a conferir outros sentidos aos saberes e valores que o determinam. Ele continua envolto em sua formasujeito, e seu mover dentro dela torna-se uma relação contraditória - uma resistência pontual.

A terceira é denominada por Pêcheux como desidentificação ou resistência ativa - termo usado para caracterizar uma espécie de assujeitamento em que o sujeito se rebela contra uma FI, deslizando para outra -, um processo no qual o enunciador torna-se sujeito da ciência, apropria-se das concepções dessa, de seu discurso pretensamente neutro para reidentificar-se sob outra formação político-ideológica que determina toda e qualquer produção científica.

\subsection{Breve revisão da literatura científica}

Estudos iniciais acerca do discurso docente e o ensino de língua, seja esta materna ou estrangeira, apontam o discurso do professor como relevante dimensão que refrata e se refrata sobre sua prática pedagógica, sua identidade, sua autoconsciência pedagógica, sua presente intelectualidade e sua formação contínua, bem como sua projeção como sujeito-profissional em relação a um futuro (ver. SOSSOLOTE, 1994; PAULA, 1996; AMARANTE, 1998; MARTINS, 1998; SANTOS, 2010). Tomando a ADF (Análise do Discurso Francesa) como referencial teórico, Sossolote (1994), por exemplo, analisa documentos oficiais do Estado de São Paulo, questionários e entrevistas com 
professores para concluir que a hiper-simplificação do discurso das ciências linguísticas no ambiente escolar por parte do estado reverbera no discurso docente de tal modo a não apenas favorecer malentendidos, mas também a solidificar concepções inadequadas e possivelmente práticas pedagógicas menos produtivas. Nesse sentido, os conhecimentos (meta)linguísticos elaborados na academia tendem a não ser plenamente aproveitados por professores de língua, que não os compreendendo claramente se sentem envergonhados e culpados (SOSSOLOTE, 1994).

Semelhantemente, Paula (1996), analisa dezenas de aulas gravas e questionários aplicados a professores de língua estrangeira para apontar suas concepções acerca de texto e leitura. Para a pesquisadora, em seu estudo de caso os professores tem a se mostrarem argumentativos e autoritários. Com efeito, a estudiosa defende que esses docentes reproduzem um paradigma tradicional de ensino de LE (Língua Estrangeira) e alimentam o continuismo da formação dos professores como última instância de uma conservadora ideologia dominante.

Amarante (1998), por sua vez, sugere em seu estudo que as estruturas institucionais que sustentam o funcionamento pedagógico da escola potencializam discursos de confissão dos docentes enquanto restringe discursos de resistência. Se por um lado a fala de outros profissionais da educação encarna o espírito neoliberal em torno da promessa de excelência, o discurso docente consolida o avesso da ideia de excelência na imagem do estudante incapaz.

Nas primeiras décadas dos anos 2000 a perspectivas teórico-metodológicas sobre o discurso docente e o ensino de línguas avançaram nessas e em outras direções. Alguns dos trabalhos que lidam com a análise do discurso de educadores procuram mais e mais explorar as nuances das relações de poder constituídas nesse discurso, incluindo também o discurso discente, o qual tende a representar o ensino de língua estrangeira como ineficiente, os cursos privados de idiomas como únicos espaços onde se adquire uma LE, a ideia do professor como agente de maior poder na sala de aula (e.g. GASPARINI, 2005). Outros trabalhos enfatizam a constituição e o funcionamento de conflitos ideológicos ou não nos enunciados de professores, com destaque para as temáticas da homogeneização na formação docente, a opressão, a alienação e a emancipação de docentes (ver. COX \& ASSIS-PETERSON, 2001; HOFF, 2001; GRIGOLETTO, 2003). Grigoletto (2003), por exemplo, aponta que professores e futuros professores de língua inglesa apresentam discursos semelhantemente contraditórios no que concerne à glorificação da língua inglesa e à assunção de um posicionamento mais nacionalístico e, talvez por isso mesmo, mais crítico e resistente à adoção desse idioma como língua franca. Em outra frente, Cox e Assis-Peterson (2001) revelam que professores do ensino básico e do ensino superior diferem substancialmente, com posicionamentos mais ou menos críticos, sobre como o ensino de inglês deve ser conceitualizado e desenvolvido. Essa dinâmica cria uma separação clara entre ambas as classes, refratando-se inclusive sobre as relações teoria-prática 
no ensino de língua estrangeira, que idealmente deveria ser orientado por uma pedagogia cada vez mais crítica, conforme sugerem as autoras.

Outros estudos deste mesmo período procuram compreender o discurso docente na relação com os contemporâneos dilemas sociais, políticos e cognitivos do discente e das comunidades em que se inserem (ver. ANJOS et al., 2009; DARÓZ, 2012; AZEVEDO et al., 2014). Azevedo e seus colegas (2014; DARÓZ, 2012), por exemplo, analisam em que medida o estranhamento, o desacordo ou o conflito emerge e interfere na relação/constituição do/entre o discurso docente e os diferentes discursos sobre o uso de tecnologias digitais no ensino de língua. Anjos e outros (2009) procuram debater questões semelhantes, mas no que diz respeito à inclusão escolar.

Por fim, algumas investigações nesse mesmo bojo da ADF, embora não necessariamente restrita a esta, exploram as particularidades do discurso docente sobre concepções de língua e formações profissional, ética e identitária dos próprios professores (ver. MARQUES, 2007, BRITO, 2011; BRITO \& GUILHERME, 2014; ARAÚJO, 2018). Em sua análise do discurso de quatro professores de curso de idiomas do estado de São Paulo, Marques (2007) discute representações dos docentes acerca do ensino-aprendizagem de LI, do gente brasileira, do falante "nativo" de LI, e acerca das línguas materna e estrangeira. Nessas análises emergem os discursos da LI como idioma internacional, o discurso da Qualidade Total do ensino, o discurso colonial, entre outros. Em última instância, Marques (2007) argumenta que as posições discursivas docentes projetam tanto a exaltação quanto a eventual resistência ao que se define por estrangeiro. Simultaneamente, esses discursos docentes se filiam a noções de incompletude profissional/intelectual, ao ideal do aprendiz bemsucedido, à LI como instrumento de legitimação (social), e oportunizam o funcionamento discursivo de papeis como colonizador, colono e colonizado. Brito e Guilherme (2014) também confirmam que os discursos docentes sobre suas experiências de aprendizagem na LI enfatizam a ideia de uma incompletude profissional e intelectual, e um anseio por se tornar sujeito na língua estrangeira.

Assim, a literatura científica produzida até aqui pode nos ajudar a entender como e se esses discursos também se apresentam, embora que de diferentes maneiras, nos enunciados de professores de outra parte do Brasil, a saber, o estado mais jovem e um dos mais pobres da federação. Dado o fato de que a maior parte dos estudos mencionados aqui se deram com sujeitos do sul ou sudeste do país, cabe-nos agora verificar e refletir em que medida essas pesquisas já revelaram o suficiente sobre o tema ou em que grau/direção precisamos continuar avançando nas análise do discurso docente, em particular no que concerne ao quadro teórico-metodológico oferecido pela ADF. 


\subsection{Abordagem metodológica}

Quanto aos procedimentos de análise, adotamos três estágios básicos propostos por Orlandi (1999), outra estudiosa da Análise do Discurso Francesa. Como apresentaremos nos parágrafos a seguir, os dispositivos analíticos de Eni Orlandi se adequam às concepções de Pêcheux no que concerne à semântica/linguagem, filosofia e materialismo histórico. Isso é possível porque esses dispositivos sugerem um sujeito que é simultaneamente locutor, enunciador e autor. Para Orlandi o sujeito no discurso não apenas é um eu na concretude linguística, ou uma perspectiva sobre os fatos e os objetos do mundo, mas também é um papel social regido por condições éticas e sócio-históricas.

Se o objetivo deste trabalho é explorar a opressão e a resistência de uma perspectiva mais fenomenológica, a compreensão de Pêcheux e Orlandi acerca do sujeito como não sendo totalmente livre ou absolutamente assujeitado parece bastante apropriada. Ao assumir a abordagem de ambos cremos ser possível observar como professores perpassam e são perpassados por seus próprios espaços discursivos e pelos do outro, pela incompletude e pelo desejo de completude, pela dispersão e a busca pela coerência, pelas estratégias polifônicas e monofônicas.

Conforme veremos a seguir, o dispositivo triplo de Orlandi (1999, p. 59) permite ao pesquisador contrastar o que é dito com o que não é, o que o sujeito diz a partir de determinada posição/lugar com o que ele diz a partir de outra, o que é dito de certa forma com o que é dito de outra forma. Sensivelmente diferente de outros tipos de analistas do discurso, para Orlandi (1999) tanto o que o sujeito expressa quanto o que ele não expressa constitui o efeito de sentido de seus dizeres em igual medida. Talvez mais profunda e criativamente, os estágios de Orlandi nos habilitam a explicar jogos simbólicos nos quais ideologia, inconsciente, processos identificatórios e gestos interpretativos se movimentam, tornando possível que sujeitos signifiquem o mundo, os outros e eles mesmos.

O $1^{\text {o }}$ estágio de Orlandi (1999) constitui-se no movimento da concretude linguística para a FD, com seus elementos de sentido, percursos, efeitos e valores. Diríamos que nessa primeira incursão precisamos estar atentos a fenômenos como a paráfrase, polissemia, metáfora e antecipação. De certo modo, esses fatos do discurso apontam para uma tensão que se catalisa entre reprodução e multiplicação de sentidos, entre unitas e multiplex, ou entre paráfrase e polissemia. Enquanto esta ( $a$ polissemia) diz respeito às possiblidades de efeitos de sentido, ao desvio, falha, equívoco e à quebra do percurso de significação, aquela (a paráfrase) nos ajuda a identificar os traços da memória do discurso, elementos-base às (re)formulações de um dizer consolidado na história/linguagem.

Já a metáfora é um processo de reinserção de coligações significantes em outro contexto. Um recurso que conecta língua e discurso, denunciando a dialética entre estrutura e acontecimento, apontando, em último nível, a FI que a determinou (PÊCHEUX 1997; ORLANDI, 1999). 
Por fim, a antecipação é um mecanismo que permite ao sujeito colocar-se no lugar do outro com quem interage. O sujeito supõe que sentidos seu interlocutor mobilizará e assim conforma seu dizer, ajustando imagens produzidas e modalizando-se para perfazer um jogo complexo e profundo.

$\mathrm{O} 2^{\circ}$ estágio trata do movimento entre as FDs e as FIs ou o processo discursivo mais amplo. Nesta etapa nosso papel será identificar a plataforma imaginária comum que une essas FDs, considerando a produção linguística que é a entrevista, seus respondentes e o momento ou espaço sócio-histórico da enunciação (ORLANDI, 1999; PÊCHEUX, 1997). Assim, nosso percurso analítico aqui seria relativizar as FDs a uma FI, sendo esta responsável por aquelas, em última instância.

Ao atingir as FIs chegamos ao $3^{\circ}$ estágio e temos visão ampla da constituição/organização discursiva que (re)produzem sentidos nas dimensões empírica e simbólica. Esse estágio seria a estrutura de resultados construídos ao fim dos procedimentos anteriores (ORLANDI, 1999).

\subsection{Outras assunções metodológicas}

Os instrumentos de geração de dados aqui empregados incluem notas observacionais, entrevistas semiestruturadas e questionários socioeconômicos aplicados a três professores de inglês em uma escola de ensino médio do município de Araguaína-TO, nas últimas semanas do mês de maio de 2012, em três dias intercalados. As entrevistas duraram entre 29 e 52 minutos. Além disso, os três docentes e seus respectivos alunos foram observados durante as aulas e demais interações entre si e com outros professores, de agosto de 2011 a junho de 2012. Portanto, a presença de algumas impressões gerais de discentes pode ser mencionada durante a análise de dados nas seções seguintes.

Inicialmente professores de muitas escolas se recusaram a serem entrevistados para este estudo, parcialmente devido ao fato de que desconfiam de pesquisadores em geral (ver. ZEICHNER, 2007; COUTINHO, 2014), e parcialmente porque muitos deles eram contratados e temiam perder seus empregos em decorrência dos efeitos de sua participação neste projeto, mesmo sabendo que suas identidades seriam protegidas. Felizmente, três docentes aceitaram o desafio. Para muitos o número pode parecer pequeno, porém o número de professores habilitados em LI no Tocantins é relativamente baixo, 365. Portanto, a quantidade de participantes representa quase $1 \%$ desse valor e quase $2,5 \%$ do número de professores alocados no município de Araguaína (MEC, 2007). Estudiosos argumentam que, no caso de uma abordagem fenomenológica como esta, não há necessidade de muitos entrevistados (MASON, 2010; MORSE, 1994). Alguns defendem que 1/2 participantes seriam suficientes a esse tipo de ângulo teórico-metodológico (SANDELOWSKI, 1995; WERTZ, 1983).

Os três sujeitos de nossa pesquisa - doravante designados por P1 (professor 1), P2 (professor 2) e P3 (professor 3) - possuem histórias de vida mais ou menos semelhantes, e que de certo modo 
ilustram a similaridade dos contextos nos quais viveram, até mesmo em virtude da idade aproximada entre eles, o fato de serem tocantinenses e graduados pela UFT (Universidade Federal do Tocantins).

\section{ANÁLISE E DISCUSSÃo DOS DADOS}

\subsection{O professor: imagens de si e da docência}

No excerto abaixo um de nossos participantes procura conceituar o que é ser professor:

1.Antes de mais nada, é um desafio, né? Tentar passar o que você conhece ou o que você busca pra ajudar aqueles que também é pra estar buscando o conhecimento, mas diante da realidade que a gente se encontra é uma... é uma dificuldade muito grande ser professor, porque você tá querendo 5.ajudar a pessoa a ser ajudada, e ele não quer ser ajudado. E, então, isso infelizmente mostra uma realidade assim louca, parece que você tá nadando contra a maré; nadando contra a correnteza, subindo, subindo... cachoeira. É assim que eu me sinto como professor, hoje, na realidade em sala de aula.

Figura 1. Excerto A (P1)

De início, P1 projeta a imagem de si como alguém que enfrenta um 'desafio', ou uma responsabilidade muito grande, talvez até um fardo (linhas 4-8). Porém, em direção ao fim da fala percebemos que esse sentido tende a se deslocar para outro bem mais pessimista. Na linha 4 , ser professor em encarar 'dificuldade', que aliás é notada como 'muito grande'. O sentido de que ser professor é ser também batalhador/persistente/insistente começa a ganhar corpo ao fim da linha 6 onde entram as metáforas do 'nadar contra a maré', 'contra a correnteza'.

Notamos que essas metáforas são comuns no discurso midiático acerca da igualdade e da diversidade, e que, como aduzimos anteriormente, se enquadram perfeitamente no cenário ideológico capitalista. Notamos também que o sentido é minimamente alterado do contexto da unidade e da diversidade, também presente na proposta curricular do estado. Aqui o professor parece ser enxergado como o profissional totalmente distinto dos demais, porque implicitamente seus colaboradores (os educandos) operam contra ele. Isso fica mais claro quando nas linhas 4 e 5 P1 desloca-se para outro lugar, assumindo o discurso da solidariedade humanística e da filantropia iluminista, colocando-se como 'ajudadora', alguém que presta favores ou piético, cuja função é facilitar a vida dos educandos.

O uso reiterado do gerúndio pode indicar que sua função é contínua e jamais se finda quando termina o expediente. Neste ponto a FD do professor, ou seja, o projeto de coesão que arregimenta os enunciados daqueles que exercem esta profissão, atribui um grande valor à realidade e à luta, ignorando outros sentidos que esses elementos possam ter em outras formações discursivas, o que pode indicar o esquecimento $\mathrm{n}^{\circ} 1$. Ademais, essa luta se configura no processo que se dá hoje, porque a ideia de amanhã se faz na incerteza (excerto A, linhas 8-9). 
De volta à análise, observamos que antes do surgimento do elemento metafórico 'cachoeira', há uma certa pausa, e P1 tenta encontrar as palavras que traduzem o que ela quer dizer. Não sabemos o que ela quis dizer, jamais o faríamos e não nos interessa aqui fazê-lo (não é esse o nosso propósito), mas podemos recuperar vestígios do processo de significação operado por essa professora.

A pausa inserida por ela não apenas lhe deu tempo pra processar os termos, mas conferiu dramaticidade ao elemento que ela introduziu: agora ser professor é 'subir' e 'subir' uma 'cachoeira'. Talvez, pelo efeito da reflexividade, ela estivesse temerosa de que o termo causasse espanto ao PP (professor-pesquisador). Se considerada essa possibilidade, notaremos o mecanismo de antecipação.

Por outro lado, a metáfora da cachoeira também traz em seu bojo a ideia de uma mulher só indo no sentindo inverso ao do demais. Novamente a noção de que os sujeitos podem ser autônomos, independentes, livres e totalmente conscientes das próprias escolhas - nota-se o funcionamento do sujeito-forma conformando P1, permitindo a interpelação ideológica capitalista que faz o homem crer que é livre e autogovernado para tomar suas próprias decisões.

Como fruto provável do discurso mecanicista, co-elaborado na filosofia de John Locke, P1 crê que ser professor é transmitir conhecimento, infundir no aprendiz o seu saber. A concepção de linguagem que subjaz a essa imagem é a de instrumento de comunicação utilizado no intermeio emissor, receptor, código e mensagem.

Vejamos o que P2 tem a dizer sobre si e o docente:

1.Pra mim, ser professor, na verdade, é ser formador de opinião. Porque um professor, eu vejo ele mais como um orientador. Ele orienta o aluno pra que o aluno forme sua própria opinião, né? A partir do conhecimento que ele tem, ele mostra o caminho que o aluno deve seguir pra chegar até o 5.conhecimento. Pra mim, isso é ser professor.

Figura 2. Excerto B (P2)

Ao introduzir sua fala P2 já parece crer não apenas na univocidade dos sentidos que invoca, mas também na superioridade daquilo que afirma, elevando-o à categoria de verdade (excerto A, linhas 1-2). É como se ao introduzir o aposto na linha 1 o docente estivesse negando todo o possível conjunto de imagens prévias que co-existem a respeito do professor.

A partir daí o discurso simplesmente informante torna-se um discurso argumentador (linha 2: 'porque'). A priori a expressão 'formador de opinião' parece ser a tradução do embate entre a FD científica em seu discurso complexo e sem seu discurso clássico. Enquanto o primeiro parece trazer para o sintagma o sentido de construção e processo - isto é, que o professor é um 'formador', um orientador, um guia das etapas educativas -, o segundo entrecruza o vocábulo 'formador' e 'opinião' para fazer emergir deles um sentido de que o professor determina o posicionamento, ensina posturas e visões sobre o mundo a seus alunos. 
Nesse sentido, é possível que a FD religiosa de P2 - isto é, o guia regulador do que se pode e deve dizer dentro de dada macro-instância discursiva - traga para esse mesmo sintagma um sentido de moralidade judaico-cristã, segundo a qual o educar é ensinar o caminho em que deve andar para que quando se cresça não haja desvios dele. Assim, o professor, como formador de opinião, conferiria aos seus alunos a sua visão, embora que crítica, sobre o mundo.

Essa interpretação se sustenta ainda mais quando ao acompanharmos o prosseguimento da fala verificamos que P2 modaliza seu enunciado, com um discurso retificador: "Ele orienta o aluno pra que o aluno forme sua própria opinião, né?” (excerto B, linhas 2-3).

Usando o mecanismo da antecipação diante do PP, o sujeito P1 anula, de certo modo, o esquecimento $\mathrm{n}^{\mathrm{o}} 2$, e sob o esquecimento $\mathrm{n}^{\mathrm{o}} 1$ assume o pretenso controle de seu dizer.

A imagem que P1 projeta a respeito do PP faz com que ele acredite que este não aceita ou não concorda com a $1^{\mathrm{a}}$ versão da imagem que ergue do docente. Ou ainda $\mathrm{P} 1$ pode ter percebido, por essa mesma estratégia emancipatória, que PP apreendeu o inventário polissêmico de sua expressão. Por isso, P1 volta para retificar e redirecionar o seu dizer inserindo a ideia de que o aluno deve ter “opinião própria”, e que o papel do professor deve ser tão somente ajudá-lo a desvelá-la/construí-la.

Ainda que usando o presente durativo, P2 continua (excerto B, linhas 3-4) e concebe o ensino como processo em que é mediador, orientador, um guia até a aquisição do conhecimento.

No excerto (C) seguinte, para além do possível reforço da metáfora do sujeito e do caminho, é interessante notar como P3 marca bem o espaço-tempo em que se encontra:

1.Ser professor, hoje, tem várias... vertentes (pausa), mas acredito que no geral ser professor é ser espelho... de uma geração de uma nação, porque o que você diz pr'um aluno, ele pode ficar gravado conforme o teu perfil... E pode ser disperso conforme também o teu perfil. Então, ser professor é estar 5 .antenado... com todas as novidades, com o perfil do teu público e com conhecimento, bagagem...

Figura 3. Excerto C (P3)

A inserção ulterior da oração "tem várias... vertentes" parece indicar que a metáfora dos caminhos se faz mais uma vez presente. As "vertentes" parecem ilustrar as vias que diferenciam cada espécime de professor no arcabouço social. É como se cada docente fosse definido pelo caminho que escolhe percorrer. Sendo que essa "vertente", sob perspectiva polissêmica, poderia indicar conjunto de princípios ou valores, forma de práxis, maneira de ver o mundo, forma de se comportar, inter alia.

Talvez essas "vertentes" sejam expressadas em termos de escolha pré-pronta, tal qual o conhecimento para ser julgado em seu status de "bagagem" ou produto finalizado. Se bem que ao considerarmos a retomada desse último vocábulo no contexto do "caminho" e das "vertentes" podemos retornar o ponto inicial de nosso debate, cujas ideias centrais são a da aprendizagem concebida enquanto viagem e a do conhecimento como experiência acumulada. 
Em uma espécie de jogo de contrastes $\mathrm{P} 3$ cria uma sutil contradição em relação à metáfora do caminho/viagem. Diz que a docência pode marcar definitivamente o aprendiz ("ficar gravado") ou desviar/perder a atenção do mesmo ("ficar disperso"). De um lado, parece haver a figura do professor centralizador, convergente, controlador, que se faz ponto de partida e foco do processo ensino aprendizagem ("ficar gravado"), de outro o docente que não é atraente, que perde o controle, que diverge, espalha, deixa solto e talvez até livre demais ("ficar disperso"). Enquanto o $1^{\circ}$ sugere univocidade, estaticidade e longa duração, o $2^{\circ}$ aponta para o equívoco, pluralidade, movimento e efemeridade - aqui o tempo, valioso a P3, reforça-se neste jogo tanto quanto no início do excerto (C).

P3 toma emprestada, então, essa imagem de professor 'espelho' (excerto C, linha 2), de modelo, exemplo. Em dado grau, isso parece um reflexo do comprometimento com certa moral religiosa segundo a qual os sujeitos devem servir de inspiração uns aos outros; ou ainda a tese paternalista e colonialista que projeta o docente como guardador e mestre dos educandos.

Por outro lado, a conclusão a que chega P3 sobre o que é ser professor parece desviar-se da assunção que ela havia feito no início da fala. Abandonando aquela concepção, que não lhe pareceu sua, ela prossegue em outra direção. Isso pode ter ocorrido porque no esquecimento $\mathrm{n}^{\mathrm{o}} 1 \mathrm{o}$ sujeito carece de estabelecer-se como fonte do seu dizer, impelindo-o a negar tudo o que está fora de sua FD.

$\mathrm{O}$ intradiscurso de $\mathrm{P} 3$ parece negligenciar essa $1^{\mathrm{a}}$ imagem discursiva em troca de outra que melhor corresponda aos valores que a determinam. P3 concebe o docente como mediador entre alunoescola-mundo. Sua função seria participar do mundo com o aluno e trazer aquele para junto deste.

Neste ponto notamos que a primeira antecipação e projeção operada por P3 pareceu confrontar-se com FD do PP ou seu projeto de coesão entre discursos, justamente o contrário do que ela imaginava ou esperava. Enquanto a segunda imagem pareceu menos distante da FD do PP, e agregada com as noções de teatro (simulacro digno de 'público' (excerto C, linha 5)), de público alvo da dinâmica mercadológica (uma noção gerada pela interpelação da FI capitalista, a saber, o conjunto de práticas modais e de significação nos discursos) e conhecimento concomitante/contextual ('novidades' [excerto C, linha 5]) ou prévio ('bagagem’ [excerto C, linha 6]).

Quando confrontamos essas imagens construtivas com outros estudos notamos que embora a combinação entre elas e o modo pelo qual se manifestam seja peculiar, há bastante pontos de contato entre o que se identifica neste estudo e outros produzidos anteriormente. A construção permanentemente pessimista da docência pode ser notada nos trabalhos de Sturm (2007) e Amarante (1998). Esta última também discute como o discurso neoliberal, que emerge nos enunciados aqui analisados, também refrata sobre as práticas de avaliação empreendidas por professores em suas salas de aula. Apesar disso, Amarante (1998) não aponta o discurso neoliberal necessariamente ligado à autopercepção do docente, como foi possível fazê-lo neste estudo de caso. 
Entre outras imagens discursivas previamente discutidas por outros pesquisadores, podemos ainda citar as ideias do professor-transmissor de conhecimento (NÓVOA, 1992), do professorescultor, professor-modelo, professor-espelho, e a noção do docente que salva os aprendizes (HOFF, 2000; NÓVOA, 1998), discurso este que perdura no imaginário brasileiro desde meados do século XIX (PASSOS, 2011). Estas imagens discursivas também se fazem presentes mais ou menos implicitamente no enunciados brevemente analisados acima. No entanto, elas emergem aqui mediante metáforas bastante incomuns e de modo a mascarar seus vestígios de inserção no enunciado e sua própria influência na estruturação do discurso que se apresenta.

De toda forma, o que notamos nessa comparação entre este estudo e alguns outros é que parecem pouco eficientes as categorias pragmático-discursivas elaboradas para compreender os modos de auto e alter-representação do professor. Categorias generalizantes ou mais herméticas, como aquelas propostas por Baladeli (2015) e outros - e.g., identidade hereditária, vocacional, romântica, entusiasta e sacerdotal -, não conseguem fazer jus às nuances, à profundidade e à complexidade da autoconstrução identitária operada pelo docente através dos múltiplos recursos disponibilizados pela linguagem verbal, conforme procuramos ilustrar acima.

\subsection{O professor: imagens acerca do ensino-aprendizagem e da disciplina de língua inglesa}

Por fim, refletimos brevemente sobre as representações do ensino-aprendizagem de LI, ou seja, a respeito da disciplina desse idioma:

\footnotetext{
1.P1: Bom, continuo partindo do princípio da dificuldade. Se trabalhar a língua portuguesa já é difícil, imagine a estrangeira. Porque a, a língua mãe eles não sabem, de uma certa forma, imagine a língua que é inserida neles depois de tanto tempo, já com a idadezinha bem avançada. Então, pra eles e 5.também pra mim é um desafio, né? ...dada a realidade da educação brasileira.

PP: Então, você quer dizer que a, o fato d'eles começarem a... estudar a língua inglesa na, no sexto ano... Você acha que é prejudicial?

P1: Com certeza, com certeza, porque a... é uma análise bem simples.

10.PP: Unrum.

P1: Se a língua portuguesa que é estudada desde quando ele nasce, que ele já tem contato desde o ta-te-be-ta-te, pode-se dizer, até a fase adulta, até a fase adulta... é ensinada, inserida constantemente, eles não aprendem (leve tom de desdém). Eles sabem muita coisa menos a sua língua-mãe, imagine a língua

15.estrangeira aonde ele já está cheio de vícios, cheio de costumes, enfim... (tentando encontrar a palavra) É mais complicado. É ensinar papagaio| velho a falar.
}

\section{Figura 4. Excerto D (P1)}

P1 inicia a construção de sua imagem declarando que é regida pelo que ela denomina de "princípio da dificuldade" (excerto D, linha 1). Isso também implica em dizer que ensinar inglês é uma luta, uma batalha que impõe riscos, sofrimentos, sacrifícios, eventuais vitórias e derrotas. Notamos como elementos do discurso emergem na fala de P1. Ou talvez eles sejam expressão do 
sistema de valores culturais que fazem com que o discurso do senso comum brasileiro circule a ideia de que os brasileiros são persistentes até o fim, não fogem à luta. Neste ponto notamos certa afetação do discurso positivista e do projeto de um Estado neoliberal que requer de seus sujeitos um mover constante em busca de 'progresso', ascensão, prestígio, e, claro, capital. Por isso a ideia do lutar é imperativo, e desistir não é uma opção (ver. SANTOS, 2010).

O questionário sobre nossos 3 sujeitos de pesquisa indica em geral que eles trabalham muitas horas por dia. Uma das razões para que isso assim se dê é a ideia, construída por Jacques Lacan (19011981), de que o capitalismo injunge nos sujeitos o ideal de mais gozar, ou seja, mais possuir. Por isso os sujeitos nunca estão satisfeitos e para atender desejos que a FI capitalista - ou seja, o imaginário discursivo que rege em dado grau a orientação de diferentes FDs - lhes impõe precisam trabalhar mais, reproduzindo cada vez mais fortemente o modo de organização social capitalista.

Provavelmente P1 exponha o mais famoso dos ditos populares no que diz respeito ao ensino de LI: "mal consegue falar português, vai falar inglês". Se não fosse pelos outros elementos de sentido aduzidos nesse mesmo excerto diríamos que se trata de uma simples repetição. Mas Pêcheux nos permite dizer que a mera repetição é ilusória, porque o deslocamento dos sentidos está sempre em processo entre o que era, é e há de vir.

Na sua 'paráfrase', P1 sugere uma visão da língua como sistema abstrato e complexo, pleno de regras idealistas; um sistema subjugado aos valores prescritivos de certo e errado.

Assim, o papel da disciplina de LI seria ensinar essa estrutura intrincada e que poucos conseguem atingir. A LI ganharia na escola, então, um caráter mais ilustrativo ou mesmo contemplativo para a maioria, pois os falantes da LM não conseguem ao menos dominá-la, sendo pouco provável a esses adquirem outro idioma. A aquisição da norma padrão da LM seria requisito necessário e indispensável para que a aprendizagem de LI seja válida.

A seguir, podemos observar outra representação bastante popularizada. Nas linhas de 2 a 6 , notamos como a reincorporação de correntes de sentido do discurso científico clássico, mais especificamente a ideia de Lenneberg (1967) e Selinker (1972) a respeito do período crítico da aprendizagem de língua, interpenetra o discurso de P1. Esta professora reproduz adiante a crença de que o adulto ou adolescente no ensino médio ('certa idadezinha') é velho demais para aprender a LI. Baseada nessa crença, que um dia já foi tomada por teoria, o idioma deveria ser inserido no currículo desde a mais tenra idade. Nesse sentido, cabe-nos esclarecer que crenças são aqui entendidas como conjunto de opiniões, percepções e ideias que sujeitos mantêm sobre o processo de ensinoaprendizagem, seus diversos aspectos, instituições e agentes (cf. BARCELOS, 2001). Este conjunto pode ser formado em referência a dimensões ou objetos do saber/experiência humana sobre os quais 
não se tem conhecimento suficiente e/ou em relações aos quais não se sente seguro, mas que se tomam como verdades, podendo, no entanto, serem questionados no futuro (DEWEY, 1906)

De volta à análise. P1 reforça sua crença cercando-se de outros elementos do discurso do senso comum, construindo a imagem de que ensinar inglês na escola pública "é ensinar papagaio velho a falar" (excerto D, linhas 16-17), isto é, ensinar uma linguagem a seres que têm reduzida ou debilitada sua capacidade de flexibilidade e adaptação cognitiva perante os objetos de conhecimento.

P1 finaliza seu turno de fala sobre o ensino de LI reforçando o conceito de um letramento autônomo, baseado em uma noção de linguagem-código, que, por sua vez, é subjugada aos padrões de certo e errado, ao valores, "vícios" e "costumes". Percebemos que essas noções todas parecem-se contrapor àquelas apresentadas pela proposta curricular (ARAÚJO, 2014).

Vejamos agora o que P2 representa em relação ao ensino de LI:

1.P2 - Pra mim é um, no caso, uma responsabilidade. Porque nós sabemos da necessidade que existe de as pessoas a cada dia estarem aprendendo mais uma língua estrangeira, sendo mais específico, o caso do inglês, né, e do espanhol, por ser as línguas mais utilizadas aqui, né? O inglês como segunda língua, na maioria dos

5.países, e o espanhol uma língua, uma linguagem predominante na nossa região. Então, eu creio que é uma responsabilidade muito grande, é, ser no caso o mediador entre os alunos e essa nova porta, né, porque pra mim aprender uma língua é uma nova porta, uma nova porta pro mundo.

Figura 5. Excerto E (P2)

P2 parece, através de um uso mais amplo de antecipações e pelo assujeitamento ao que ele acredita serem verdades universais, construir um discurso informante e justificador. Por assujeitamento, queremos dizer o processo pelo qual o docente se identifica com determinados discursos que o vão determinando em seu dizer, orientando-o à medida que se estabelece enquanto sujeito-forma e ocupa esta e aquela posição de enunciador na redes de relações discursivas.

Primeiro ele se conforma à sua forma-sujeito, reconhecendo que o ensino de LI é uma responsabilidade pessoal dele e, por conseguinte, do aparelho estatal. A visão althusseriana de Estado nos ensina que o controle que este mantém em relação aos sujeitos tende a individualizá-los, o que pode dar-lhes a sensação de que são peculiares e responsáveis por si.

Quando P2 diz, "nós sabemos”, ele antecipa que as informações que ele vai lançar é do conhecimento de todos, sobretudo do seu interlocutor imediato. Por outro lado, esta estratégia pode ser apenas um simulacro pelo qual P2 implica que outros não sabem, e por isso, para justificar sua assunção lança dados a respeito dos motivos e contexto de escolha da LI para o currículo escolar.

Novamente podemos observar como FD científica, ou seja, a tentativa de harmonizar diferentes discursos sob um macro-escopo ou intenção, coopera junto à organização intradiscursiva do sujeito fazendo com que ele estruture sua fala em uma maneira de dissertação e argumentação ao 
mesmo tempo (excerto E, linhas 2-6), que é uma ordenação tipológica caracteristicamente atribuída aos discursos das ciências. O modo como esse evento ocorre em P2 poderia ser corroborado também pelo fato de que ele costuma lê, embora não frequentemente, periódicos de divulgação científica, o que de certa maneira pode ter colaborado para essa configuração gênero-discursiva de sua fala.

P2 reforça a imagem do professor de inglês como mediador, e da língua como meio de acesso e prática. Para ele o compromisso e responsabilidade em LI é a de possibilitar o acesso a outros conhecimentos e outras formas de saber disponíveis apenas naquele idioma.

Indicando a superioridade relativa do inglês para com espanhol, P2 atribui maior relevância ao primeiro, designando-o "nova porta para o mundo" (excerto E, linhas 5-6).

Por último, observemos o que P3 constrói a respeito da disciplina de LI:

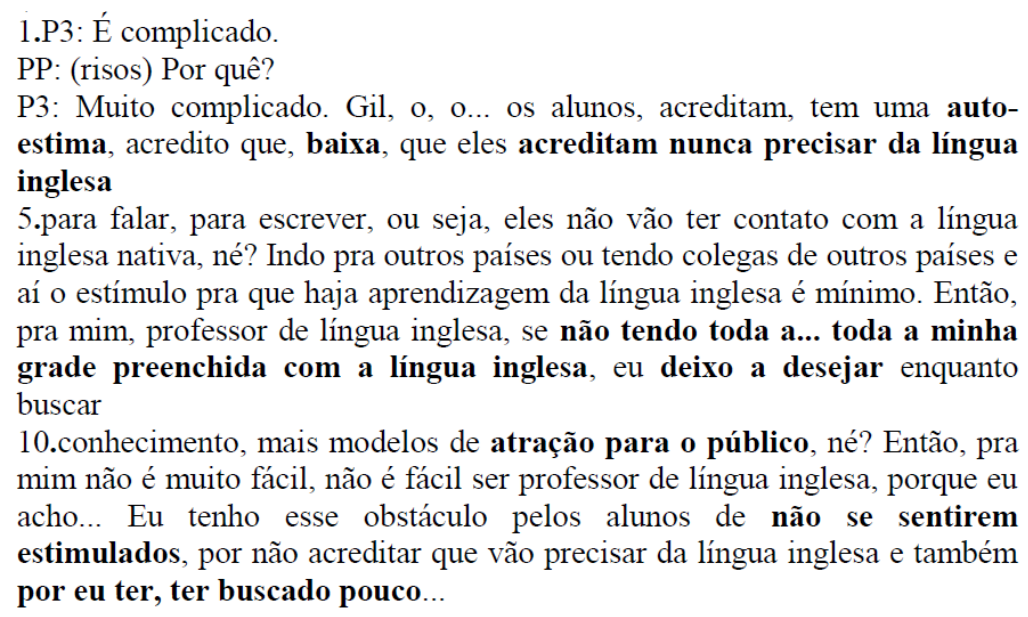

Figura 6. Excerto F (P3)

Em certa perspectiva P3 parece se aproximar mais de P1 quanto à concepção de disciplina de LI, à medida em que se distancia das assunções de P2. P3 entende que o ensino de LI na escola é complicado, o que pode significar (levando em conta suas FDs e os elementos anteriormente tomados em seu intradiscurso) que é difícil, árduo, trabalhoso.

Enquanto a palavra 'complicado' parece afastar P3 do prazer ou satisfação em ensinar LI, a palavra 'dificuldade' conduz P1 para o sentido bélico de que ensinar inglês na rede pública é travar batalhas cotidianas contra a incapacidade dos educandos e a falta de condições no ambiente escolar - o que ela chama de "realidade da educação brasileira", sintagma no qual o adjetivo último parece (considerando a expressão facial de P1 no momento em que ela reproduz essa fala) depreciar ou dar ares de pessimismo a essa realidade.

P3 crê que o ensino de LI deve basear-se na premissa e na esperança de que os alunos possam ir ao exterior para usar a língua em contextos reais. Pressupondo a artificialidade do ensino, ao mesmo tempo em que concebe um letramento autônomo, e uma visão de língua como instrumento de comunicação, P3 atribui a falta de vontade dos alunos de aprenderem LI à baixa estima dos mesmos. 
Ela localiza no domínio psicológico o princípio dos motivos para se aprender uma língua estrangeira: "Eu tenho esse obstáculo pelos alunos de não se sentirem estimulados, por não acreditar que vão precisar da LI e também por eu ter, ter buscado pouco [...]” (excerto F, linhas 12-14).

Depois, P3 atribui às suas próprias limitações em relação ao domínio de LI como fator que desestimula os alunos na disciplina. Em justificativa pessoal, ela procura explicar que não tem domínio suficiente do idioma, além da sua carga horária nessa matéria ser reduzida (excerto F, 7-10). P3 acaba por colocar a si e ao educando lado a lado. Atribui a ambos a falta de estímulo, o 'buscar pouco', e implica em dizer que se os alunos tem uma estima baixa, o que os faz não se interessar pela língua, ela também poderia tê-la, já que diz não ter se interessado em aprimorar suas habilidades linguísticas. Os elementos da FD do aluno, ou do projeto que regula seu dizer, são projetados e refletidos na FD de P3 de modo a deslocar os sentidos do que ela entende por LI, fazendo com que P3 creia que realmente é essa a postura dos alunos em relação à disciplina: uma tentativa de paráfrase se torna um deslocamento mais profundo.

Ao invés de atribuir a responsabilidade de suas limitações em relação a LI a outros fatores contextuais, a interpelação da FI capitalista, isto é, a complexa conjunção de práticas significantes desse modo de produção, e a modalidade de sujeição universal ao sujeito-forma jurídico impelem P3 a culpar-se por seu suposto insucesso. No caso da mulher, como o é P3, a consolidação do capitalismo trouxe para junto dela atribuições de uma sociedade mercantilista e mais elementar (mãe/esposa/zeladora) para mesclá-las com a da pós-modernidade (professora/médica).

No avesso do desejo que P3 manifesta em tornar-se 'atração' teatral para o público (excerto F, linha 10; excerto C, linha 5), percebemos que sua frustração pode ser aprofundada.

Nossos participantes também nos permitem operar interpretações sobre modos específicos pelos quais estes ancoram os sentidos de ensinar-aprender LI: 


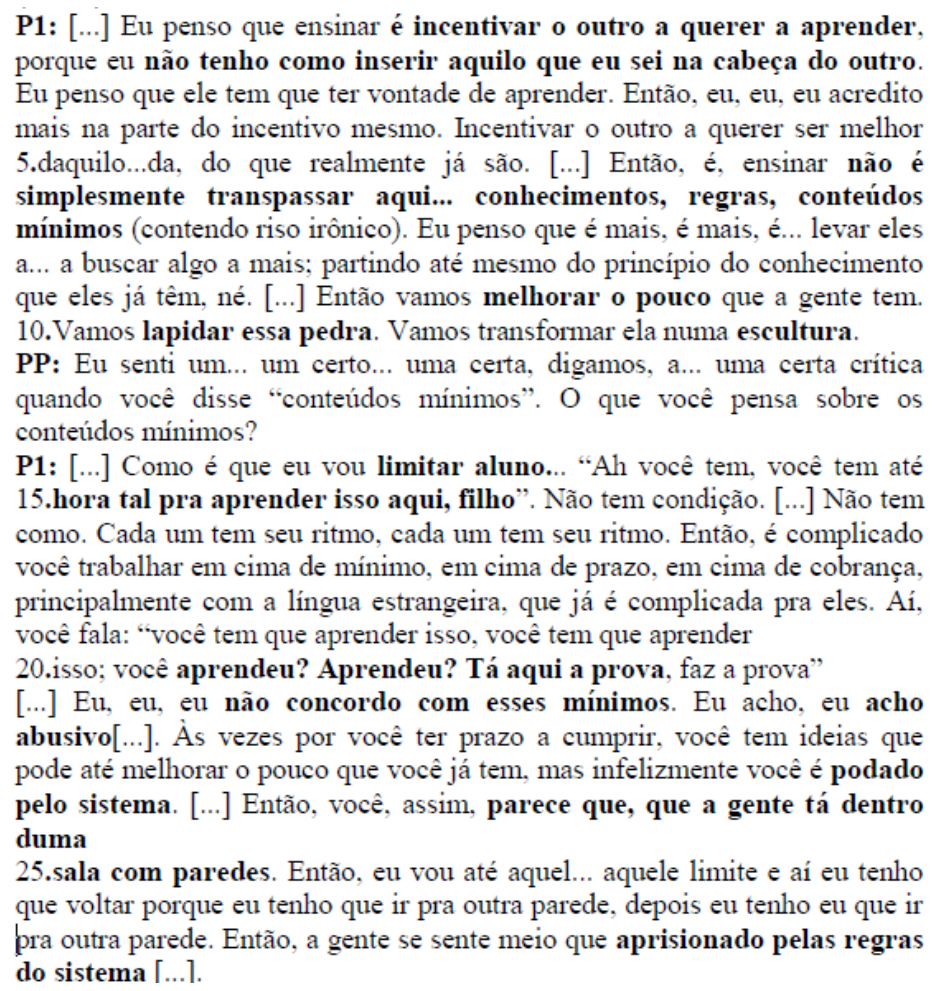

\section{Figura 7. Excerto G (P1)}

Quando questionada sobre o significado de se ensinar P1 parece entender que a o exercício da docência se rege pelo desejo e pelos empecilhos que se lhe apresentam. Basta observar como são enfáticas as múltiplas retomadas do termo "incentivo", a circulação dos vocábulos "querer", "vontade", "levar", e o efeito parafrásico da forma verbal "vamos", bem como a referências às "regras", "aprisionamento" e "sistema" (cf. SANTOS, 2010).

Parece haver uma contraposição entre desejo e obstáculos na qual podemos localizar os sentidos de batalha e dificuldade, tão insistentemente atribuídos ao ensino-aprendizagem de LI quer por P1, quer por P3. Ambas parecem identificar-se mais com a FD do proletariado docente em muitos enunciados, talvez na maioria deles. Fazemos exceção a P2, aparentemente tomado por um processo identificatório tanto em relação aos valores da FD protestante, especificamente da doutrina Batista pela qual constrói em seu discurso sentidos de entusiasmo, esperança e persistência -, quanto em relação à FD científica pela qual, às vezes, parece operar um contra-identificação diante da FI capitalista, mas ao fim, como é de se esperar de qualquer posição contra-identificatória, acaba por não oferecer uma significativa resistência à FI capitalista ou ao supra-ideário discursivo vigente, ao contrário, apenas realiza sua manutenção - conforme notaremos durante nossas análises.

As "regras", a norma, a prescrição e o "sistema", aparentemente reforçados e suportados por P1 anteriormente (quando discorremos sobre a metáfora do papagaio), podem ter sofrido agora um desvio e recebem outro sentido. Antes essas noções pareciam ser princípios imprescindíveis a serem adquiridos e exercitados em relação à LM, a fim de que fosse viável a aprendizagem da LI. Agora, 
em um movimento de contradição intradiscursiva, esses mesmos elementos mostram-se antagônicos, e parecem estorvar não apenas a disciplina de LI (excerto G, linhas 5-9), mas também a liberdade de ação do próprio docente (excerto H, linhas 19-28).

P1, que antes fazia circular certa defesa do ensino de LI como fortemente dependente da gramática normativa, agora parece antagonizar essa mesma prescrição. Essa contradição que emerge quanto ao ensino da gramática normativa quer nas aulas de LI, quer nas aulas de LM ocupam um grande espaço nas produções científicas sobre o tema.

A seguir, temos a impressão de que P1 adquire uma semiconsciência em relação ao discurso do aparelho estatal que o subjuga. Nesse sentido encontramos as referências ao "abusivo" (excerto G, linha 21), "podado" (excerto G, linha 23), à "sala com paredes" (excerto G, linha 25), ao "aprisionado" (excerto G, linha 27), bem como as reivindicações sobre os conteúdos mínimos, a insatisfação com as condições espaço-temporais no exercício da docência, e, por fim, a denúncia de negligência sobre as diferenças individuais de aprendizagem (excerto G, linhas 14-19). Além disso, a FD científica, ou o guia regulador dos discursos da ciência, parece presente em P1, já que notamos paráfrases do discurso Freiriano acerca da educação bancária (excerto G, linhas 2, 5-7).

Porém, com leitura mais atenta, notamos que o mesmo aparelho estatal contraposto por P1 assujeita-o no intradiscurso, ou seja, compele certo grau de determinação da sua fala ou favorece sua identificação com dados discursos e não outros, projetando-o como sujeito-forma e em certas posições na plataforma relacional do discurso. As repetições da forma verbal "vamos" parece evocar a ideia proletária do encorajamento solidário, mas o "lapidar de pedras" (excerto G, linha 10) aponta em outra direção, a de que os trabalhadores docentes têm a responsabilidade coletiva de transmutar a situação dos incultos ou indoutos a fim de "melhorar" (excerto G, linha 9), ou talvez alcançar os padrões e normas manifestados pelos mesmos discursos documentados diante dos quais a professora se sente oprimida.

Diante de uma nova contradição em relação ao discurso freiriano (a educação como processo de libertação), a ideia da "escultura" (excerto G, linha 10) traz de volta visões de uma educação clássica, em que o papel do docente é adestrar, polir, corrigir, lapidar o potencial dos educandos, submetê-los às prescrições da língua. O professor, sendo escultor, poderia fazer o que bem desejasse com a matéria que lhe chega às mãos. Contudo, nessa "sala com paredes" (excerto G, linha 25), e provavelmente sem portas, o artista é oprimido e abusado, não faz o que quer, mas o que lhe permitem.

Agora, vejamos como P2 representa esse mesmo ensino sobre o qual discorre P1: 
P2 - Nossa, ensinar pra mim é um privilégio. Porque, assim, um, eu creio que, pelo menos pra mim, é um orgulho poder encontrar, por exemplo, com ex, ex-alunos bem sucedidos. E poder olhar, e saber que eu contribui com, com alguma coisa na carreira deles. Inclusive, pra mim, esse, isso é a recompensa maior pro professor. Então, ensinar, pra mim, é um privilégio, não é um trabalho, é um privilégio. [...]

Figura 8. Excerto H (P2)

De início podemos notar a presença de elementos discursivos da FD religiosa protestante, interpelados pela FI capitalista e presentes nas noções de "privilégio", "crença" e "orgulho". Talvez não pudéssemos dizer que se trata de uma paráfrase, no sentido estrito, mas possivelmente ser-nos-ia permitido indicar uma retomada de valores cristãos, não apenas com relação ao ensino, mas também com relação a si mesmo enquanto docente.

Já em P3 o enfoque discursivo percorre outras direções. Senão, vejamos:

PP: É... Pra você o que significa ensinar?

P3: Se dar, ensinar quer dizer se dar, se entregar. É por isso que eu digo que eu sou falha na língua inglesa, porque eu não me dou por completo. $[\ldots]$

Figura 9. Excerto I (P3)

Como dissemos anteriormente, as ideias de dificuldade e luta parecem ser muito fortes quando P3 representa o ensino de LI. Se entendermos que nas outras falas houve discurso que concebe docência como resistência, teríamos nesse novo excerto uma contradição absoluta: docência/ensino seria rendição/entrega, o que poderia, a partir de dado ângulo, anular nossas interpretações anteriores.

Porém, se pensarmos que os elementos dificuldade e luta são complementares do termo sacrifício, poderemos visualizar melhor os sentidos de "entrega" e "doação" suscitados no excerto I. Assim, eles vêm associados a lamento/confissão de culpa em face de um insucesso.

P3 é mulher, casada, não tem filhos, é negra e cristã. Essa "entrega", tanto quanto essa autodepreciação (“sou falha”), se vistos a partir desses múltiplos lugares de onde ela se expõe, podem apontar para o fato de como ciência e religião ergueram estruturas e sustentaram, em algum tempo, estruturas discursivas que pregaram a submissão da mulher e dos negros.

Indiferente aos numerosos fatores e circunstâncias que determinam sua prática, P3 não apenas se representa como "falha", mas também atribui sua incapacidade ao fato de não ter se entregue "por completo" ao ensino. Ou talvez poderíamos supor que tal entrega aponta um desejo de fluência não atingida. Nesse sentido, a entrega de si estaria sendo negligenciada em relação à LI.

Além de supor que ela deva se sacrificar após tanta "dificuldade" e "luta" (como ela mesma conceitua a docência), P3 julga que seu esforço é insuficiente. Esse é um dos indícios da interpelação capitalista que tão bem a sustenta, a representação da culpa/auto-fracasso, conforme sugerido antes. 
Uma vez mais, a começar pela ideia de que ensino-aprendizagem de LE se infunde em luta e sofrimento (BARATA, 2006; ver. SANTOS, 2010), muitas dessas construções discursivas estão presentes em estudos de outros pesquisadores. A diferença deste estudo é novamente a conexão mais generalizada entre essas imagens discursivas e a vida que se desenrola no ambiente escolar. Barata (2006), por exemplo, demonstra como a imagem de sofrimento e batalha se conecta mais ao processo avaliativo do que a outros aspectos da do ensino. Não é o caso deste estudo, já que essa construção discursiva particular parece estar mais ligada à docência, à escola, ao estado e ao ensinoaprendizagem como um todo e não a uma dimensão educacional específica.

Além disso, notamos que a emergência do discurso positivista nos enunciados docentes, embora notada por outros investigadores da área, ocorre aqui de maneira muito mais sutil e provavelmente mais incidental do que nos exemplos fornecidos por Amarante (1998), Martins (1998) ou Baghin-Spinelli (2002). O mesmo não ocorre com a noção de progresso por intermédio da educação. Aqui, esta construção pode ser considerada tão patente quanto nas falas dos sujeitos de pesquisa em Coracini (1997) ou Hoff (2001).

Quanto a influência de fatores como idade e "vícios de linguagem”, ao lado da ausência de estímulo e excesso de artificialidade, estas imagens discursivas também são discutidas por outros linguistas, tais como Bahin-Spinelli (2002), Sossolote (1994), Brito (2011) e Baladeli (2015), respectivamente. Não obstante, o fator idade, por exemplo, aparece em boa parte como tópico de debate ou questionamento dos estudos discursivos sobre docentes. No caso de nosso estudo a construção significante vem à tona por meio de uma metáfora bastante comum no imaginário brasileiro, mas utilizada quase que de forma acidental pelo enunciador. Com efeito, nesta investigação ficariam mais evidentes os mecanismos de autorregulação empregados pela FD docente no controle do dizer.

Por fim, é interessante observar que a imagem do ensino-aprendizagem como performance ou ação teatral, e a do professor como potencial ator. Embora, Nóvoa $(1992 ; 1998)$ não contemple essa possibilidade específica em seus estudos sobre a formação identitária docente, e a noção do teatro-ator não seja particularmente surpreendente e possa ser forçada para se conformar à categoria do professor entusiasta, de Baladeli (2015), essa é uma perspectiva sobre a identidade do processor que precisa ser melhor explorada. Isso precisa ocorrer não somente do ponto de vista do discurso, bem como a partir da análise das práticas e outras esferas pertinentes à docência.

Em todo caso, este estudo não poderia empreender uma discussão mais ampla acerca dessas categorias de política identitária do professor ou sobre o ensino-aprendizagem de LE em geral, já que nossa abordagem aqui considera apenas o discurso do docente, suprimindo, portanto, outras dimensões mais ou menos discursivas pelas quais a identidade se faz, a saber, a prática, a interação, 
a história de vida e formação, as estruturas socioeconômicas, os aparelhos estatais e suas regulações. Além disso, esta pesquisa tem origem fenomenológica e seu número de participantes limita consideravelmente o poder de generalização de nossas constatações.

Nesse sentido, e no intuito de contribuir para que outros também possam fazer avançar as pesquisas sobre identidade docente, cabe-nos acrescentar que são necessários mais estudos longitudinais acerca da construção e desenvolvimento da identidade docente, bem como acerca do exercício da docência. Dito de outro modo, precisamos de investigações que incluam mais significativamente períodos prolongados de tempo e interações de fatores oriundos de múltiplas ordens, para além daqueles mais inerentemente sociodiscursivos. Por conseguinte, cremos que ao empreender estudos mais robustos e abrangentes, com mais participantes do que perspectivas fenomenológicas recomendariam, e de preferência com a colaboração de pesquisadores de diferentes áreas, analistas do discurso poderão colaborar mais consistentemente para a compreensão e reflexão acerca da docência e de suas implicações no ensino-aprendizagem como um todo.

\section{CONSIDERAÇÕES FINAIS}

Como observamos nas breves análises acima, não é necessariamente o conteúdo dos enunciados dos docentes que revela algo novo sobre a construção discursiva da docência em LE, mas estratégias utilizadas para tanto. Em verdade, muitas dessas imagens discursivas aqui aduzidas aparecem sob diferentes configurações em múltiplas instâncias discutidas por outros linguistas aplicados. No entanto, o que torna valiosa a análise do discurso de docentes nessa parte tão mais remota do Brasil são os modos inusitados pelos quais esses discursos são reelaborados, ressignificados, combinados com outros discursos e apresentados. Isso quer dizer que a relevância última de ouvirmos as vozes desses profissionais talvez resida no fato de que eles fornecem uma visão privilegiada acerca das dinâmicas socio-interacionais e dos arranjos semântico-discursivos, que parecem bastante particulares deste cenário setentrional do país.

Assim, para facilitar a retomada dessas vozes, de nossas discussões acerca delas e para contribuir em favor de uma reflexão mais aprofundada sobre os temas aqui debatidos, procuramos sintetizar nossas conclusões a partir de quatro tópicos, os quais são apresentados a seguir.

Quanto aos valores atribuídos ao ensino-aprendizagem de LI. O prestígio e o status social, que, ao nosso ver, tanto parecia ocupar um lugar cativo no centro dos dizeres a respeito do ensino de LI ou da própria língua inglesa, cedeu um significativo lugar à ideia popular de batalha e sofrimento, uma interpelação capitalista que subjuga os docentes às exigências de desenraizamento, vínculos trabalhistas, mobilidade e dispersão identitária de classe. Por sua vez, os valores de conquista, 
autorrealização e ganhos financeiros parecem se constituir em significantes simulados, movediços/silenciosos. A conquista seria virtual porque parece sempre encontrar-se no "há de vir", através da reiteração dos enunciados docentes. Os ganhos financeiros não são mencionados, é como jamais existissem, e talvez sofram apagamento. Por outro lado, parece-nos que a autorrealização submete-se a um silenciamento.

Por fim, observamos a emersão de um valor a respeito do qual nunca havíamos pensado com seriedade porque o considerávamos excludente e insignificante, ou banal, a saber, a superioridade intelectual. P1 ilustra bem esse elemento quando sugere que o professor de inglês está acima de outras pessoas por dominar o idioma, enquanto P3 confirma indicando que o docente de LI "fala difícil", e P2 não está longe dessa dinâmica quando entende a docência em LI como um privilégio.

Das representações discursivas acerca da relevância e papel da LI. Perpassados pela FI capitalista, professores buscam no sistema econômico (ou no uso/utilidade) as respostas para os porquês do ensino de LI no Tocantins - cf. com a tese da educação como redentora da economia (GALVÊAS, 1993). Na construção de suas imagens discursivas, reconhecem o lugar do inglês na formação humanista, e tendem a apontar a utilidade/uso como fator mais relevante. Nas representações docentes, ao contrário do que imaginávamos, a aprendizagem de LI não parece ser consideravelmente ancorada na função propedêutica da educação secundária, isto é, na meta de obter vaga na universidade.

Quanto aos deslocamentos de posição e espaço/formação discursiva. Os movimentos perfeitos pelos docentes em suas identidades parecem ser marcados pelo distintivo, e ao mesmo tempo pelo "unificante". Uma forte imagem de si erguida pelo professor é a de que ele é um eterno sofredor e batalhador. Como indicamos anteriormente, essa representação não se refere apenas às identidades do professor, mas já se incorporou ao imaginário brasileiro (cf. BARATA, 2006; BALADELI, 2015). Para além do status de fruto da interpelação capitalista, essas identidades parecem ser impulsionadas por valores da FD religiosa sobre os docentes.

Quanto ao letramento e ensino-aprendizagem de LI. Nesse sentido, P1 e P3 ilustram bem visões relativamente colonizadas com relação à LI, seus usuários e cultura. Em outras palavras, diríamos que há forte tendência por parte dos aprendizes em julgar esse idioma como mais belo/difícil, e que, portanto, só pode ser adquirido seres superiores, cujos cérebros gozam de maior capacidade.

Assim, é responsabilidade da comunidade escolar, e não apenas dos professores, disseminar a ideia de que o inglês é um idioma como qualquer outro e que o prestígio de que goza advém quase que exclusivamente do sucesso econômico das nações que o adotam.

Outrossim, somos convocados por uma perspectiva ideológico a entender, da mesma forma que sugere P2, que a aprendizagem de línguas, tal qual o letramento, é multimodal. Não precisamos 
ficar restritos às proposições do livro didático, tampouco abandoná-las por completo. Mas, com um pouco de visão e disposição avançar para além dos textos escritos em preto e branco, e das músicas.

Temos percebido que o letramento requer que a escola seja mais que uma janela do mundo, que se faça parte dele trazendo-o virtualmente para suas fronteiras físicas, que é o único obstáculo real e, ainda assim, o mais transponível entre todos. Para isso é necessário que o ensino de LI parta para os ambientes digitais (ou não) como Facebook, Youtube, bate-papo, jogos eletrônicos; para os gêneros não-canônicos como mangá, revista em quadrinho, piadas, cartoons, mensagens e jogos eletrônicos. É indispensável que sejam facultadas ao aprendiz oportunidades significativas para que ele mesmo (a partir das escolhas que lhe forem ofertadas e outras mais por ele fomentadas) entre em contato com um inglês autêntico, falado e/ou escrito por pessoas reais e comuns, célebres e anônimas.

Em face de todas as potencialidades apresentadas pela aprendizagem de LI, torna-se improfícuo relegá-la a uma posição menosprezada e subalterna com relação a outras disciplinas. Assim, um letramento mais crítico convida professores de inglês a revitalizarem seus objetos de ensino no âmbito escolar por intermédio de outros professores, saberes, atividades, informações e ações que ultrapassem os limites do metalinguístico, ou o ensino sobre a língua. Afinal, letramento é basicamente firmado no exercício da interação e das práticas sociais em seus variados contextos, não faria sentido um ensino de língua desvinculada do esporádico prazer e da constante (res)significação das práticas didáticas.

\section{REFERÊNCIAS}

AMARANTE, M. de F. S. Ideologia neoliberal no discurso da avaliação: a excelência e o avesso da excelência. 1998. 298 f. Tese (Doutorado em Linguística Aplicada) - Universidade Estadual de Campinas, Instituto de Estudos da Linguagem, Campinas, 1998.

ANJOS, H. P. dos et al. A inclusão escolar do ponto de vista dos professores: o processo de constituição de um discurso. Revista Brasileira de Educação, v. 14, n. 40, p. 116-129, 2009.

ARAÚJO, A. G. Representações sobre o ensino-aprendizagem de língua inglesa: entre os documentos oficiais e a fala do professor da escola pública. 2014. 183 f. Dissertação (Mestrado em Língua e Literatura) - Programa de Pós-Graduação em Letras, Universidade Federal do Tocantins, Araguaína, 2014.

ARAÚJO, A. G. O Tocantins e seu ensino de inglês na proposta curricular para o ensino médio: entre expectativas e silenciamento. Revista Leia Escola, v. 18, n. 3, p. 145-163, 2018.

AZEVEDO, N. P. G. et al. O professor e as novas tecnologias na perspectiva da análise do discurso: (des) encontros em sala de aula. Linguagem em (Dis)curso, v. 14, n. 1, p. 15-27, 2014.

BAGHIN-SPINELLI, D. C. M. Ser professor (brasileiro) de língua inglesa: um estudo dos processos identitários nas práticas de ensino. 2002. 199 f. Tese (Doutorado em Linguística Aplicada) - Instituto de Estudos da Linguagem, Universidade Estadual de Campinas, Campinas, 2002. 
BALADELI, A. P. D. Narrativas da identidade do professor de língua inglesa: o legado do PIBID. 2015. 238 f. Tese (Doutorado em Letras) - Programa Pós-Graduação em Letras, Universidade. Estadual Oeste Paraná, Cascavel, 2015.

BARATA, M. C. C. M. Crenças sobre avaliação em língua inglesa: um estudo de caso a partir das metáforas no discurso de professores em formação. 2006. 237 f. Tese (Doutorado em Linguística Aplicada) - Programa de Pós-Graduação em E. Linguísticos, Universidade Federal de Minas Gerais, Belo Horizonte, 2006.

BARCELOS, A. M. F. Metodologia de pesquisa das crenças sobre aprendizagem de línguas: estado da arte. Revista Brasileira de Linguística Aplicada, v. 1, n. 1, p. 71-92, 2001.

BRASIL, Ministério da Educação. Desempenho médio do Enem 2006. Brasília: SEB, 2007.

BRITO, C. C. de P. Discurso(s) sobre o ensino de língua materna em um curso de formação de professores. Revista Brasileira de Linguística Aplicada, v. 11, n. 3, p. 633-665, 2011.

BRITO, C. C. de P.; GUILHERME, M. F. F. Memorial de aprendizagem e a formação do professor: vozes constitutivas da relação aprender/ensinar línguas estrangeiras. Revista Brasileira de Linguística Aplicada, v. 14, n. 3, p. 511-531, 2014.

CORACINI, M. J. R. F. A Escamoteação da Heterogeneidade nos discursos da Linguística Aplicada e da Sala de Aula. Revista Letras, v. 14, n. 1, p. 39-64, 1997.

COUTINHO, R. X. et al. Aproximando universidade e escola por meio do uso da produção acadêmica na sala de aula. Ciências e Educação, v. 20, n. 3, p. 765-783, 2014.

COX, M. I. P.; ASSIS-PETERSON, A. A. de. O professor de inglês Entre a alienação e a emancipação. Linguagem \& Ensino, v. 4, n. 1, p. 11-36, 2001.

DARÓZ, E. P. O discurso do professor de língua inglesa sobre docência na era digital. 2012. 143

f. Dissertação (Mestrado em Ciências da Linguagem) - Universidade Católica de Pernambuco, Recife, 2012.

DEWEY, J. Beliefs and Realities. Philosophical Review, n. 15, v. 1, p. 113-129, 1906.

FSP, Folha de São Paulo. Veja o desempenho da sua escola no Enem 2018. São Paulo: Grupo Folha, 2019. Disponível em: https://www1.folha.uol.com.br/educacao/2019/06/veja-o-desempenhoda-sua-escola-no-enem-2018.shtml. Acesso: 27 maio 2019.

G1-NOTÍCIAS. Resultado do Enem-2007 foi $40 \%$ melhor que ano anterior. Rio de Janeiro: Organizações Globo, 2008. Disponível em: http://g1.globo.com/Noticias/Brasil/0,,mul3873385598,00-resultado+enem.html Acessado: 05 ago. 2013.

G1-NOTÍCIAS. Veja o resultado do Enem 2009. Rio de Janeiro: Organizações Globo, 2010. Disponível em: http://g1.globo.com/veja-o-resultado-do-enem-2009.html Acesso: 05 ago. 2013. GALVÊAS, E. Educação no Brasil: a economia brasileira e suas perspectivas. Edições ANPEC, v. 1, n. 32, 1993.

GASPARINI, E. N. Sentidos de ensinar e aprender inglês na escola de ensino médio e fundamental - uma análise. Polifonia, v. 1, n. 10, p. 159-175, 2005.

GRIGOLETTO, M. Um dizer entre fronteiras: o discurso de professores e futuros professores sobre a língua inglesa. Trabalhos em Linguística Aplicada, v. 1, n. 41, p. 39-50, 2003.

HOFF, B. M. E. O dizer da prática: um discurso constitutivo da formação do sujeito-professor de língua materna. Dissertação (Mestrado em Letras) - CAL, UFSM, Santa Maria, 2000. 
HOFF, B. M. E. Dizer da prática do sujeito-professor de língua materna: um estudo discursivo. In: CORACINI, M. J.; PEREIRA, A. E. Discurso e sociedade: práticas em análise do discurso. Pelotas: UCPel, 2001, p. 87-102.

LACAN, J. De um outro ao outro. In: MILLER, J. A. (org.). O seminário 16 de Jacques Lacan: 1968-1969. Rio de Janeiro: Zahar, 2008. p. 119-253.

LENNEBERG, E. H. Biological Foundations of Language. New York: John Wiley, 1967.

MARQUES, L. O. C. Representação e identidade: uma análise de discurso de professores de inglês de escolas de idiomas. 2007. 119 f. Dissertação (Mestrado em Letras) - Departamento de Língua Estrangeiras Modernas, Universidade de São Paulo, São Paulo, 2007.

MARTINS, L. C. P. Conflitos e contradições na formação de professores: um estudo das práticas discursivas da disciplina prática de ensino de língua inglesa. 186 f. Dissertação (Mestrado em Linguística Aplicada) - Instituto de Estudos da Linguagem, Universidade Estadual de Campinas, Campinas, 1998.

MASON, M. Sample size and saturation in $\mathrm{PhD}$ studies using qualitative interviews. Forum Qualitative Sozialforschung, v. 11, n. 3, p. 1-19, 2010.

MEC, Ministério da Educação. Censo do Professor. 2007. Disponível em: http://portal.mec.gov.br/plano-nacional-de-formacao-de-professores/censo-do-professor. (Acessado: 21 de julho de 2012).

MORIN, E. Introdução ao Pensamento Complexo. 5. ed. São Paulo: Instituto Piaget, 2008.

MORSE, J. M. Designing qualitative research. In: DENZIN, N. K.; LINCOLN, Y. S. (org.). Handbook of qualitative inquiry. Thousand Oaks: Sage, 1994. p. 220-235.

NÓVOA, A. Formação de professores e profissão docente. In: NÓVOA, A. (org.). Os professores e sua formação. Lisboa: Dom Quixote, 1992. p. 13-31.

NÓVOA, A. Relação escola-sociedade: novas respostas para um velho problema. In: SERBINO, L.E. et al. (org.). Formação de professores. São Paulo: UNESP, 1998. p. 19-39.

ORLANDI, E. Gestos de leitura: da história no discurso. Campinas: Unicamp, 1997.

ORLANDI, E. Interpretação: autoria, leitura e efeitos do trabalho simbólico. Petrópolis: Vozes, 1998.

ORLANDI, E. Análise de discurso: princípios \& procedimentos. Campinas: Pontes, 1999.

PASSOS, M. A mística e o mito da era de ouro do magistério: trabalho, profissão e vocação percurso histórico em Minas Gerais (1892-1977). In: PASSOS, M. (org.). A mística da identidade docente: tradição, missão, profissionalismo. Belo Horizonte: Fino Traço, 2011. p. 91-124.

PAULA, M. M. S. de C. M. de. A interferência da formação do professor em aulas de leitura em língua estrangeira. 1996. 243 f. Dissertação (Mestrado em Linguística) - Instituto de Estudos da Linguagem, Universidade Estadual de Campinas, Campinas, 1996.

PÊCHEUX, M. Semântica e discurso: uma crítica à afirmação do óbvio. Campinas: Unicamp, 1995. PÊCHEUX, M. Análise Automática do Discurso. In: GADET, F.; HAK, T. (org.). Por uma Análise Automática do Discurso: uma introdução à obra de Michel Pêcheux. Campinas: Unicamp, 1997.

PÊCHEUX, M. O Discurso - estrutura ou acontecimento. Campinas: Pontes, 2006.

SANDELOWSKI, M. Focus on qualitative methods sample size in qualitative research. Research in Nursing \& Health, vol. 18, n. 1, p. 179-183, 1995. 
SANTOS, J. S. dos. Discurso sobre e de professores de língua materna no estado do Tocantins: modos de posicionamento do e em relação ao discurso oficial. 2010. Tese (Doutorado em Linguística Aplicada) - Instituto de Estudos da Linguagem, Universidade Est. de Campinas, Campinas, 2010.

SELINKER, L. Interlanguage. Inter. Review of Applied Linguistics, v. 10, n. 1, p. 209-231, 1972.

SOSSOLOTE, C. R. C. O discurso de vulgarização da linguística no aparelho escolar. 1994.

Dissertação (Mestrado em Linguística) - Instituto de Estudos da Linguagem, Universidade Estadual de Campinas, Campinas, 1994.

STURM, L. As crenças de professores de inglês de escola pública e os efeitos na sua prática: um estudo de caso. 2007. 138 f. Tese (Doutorado em Letras) - Programa de Pós-Graduação em Letras, Universidade Federal do Rio Grande do Sul, Porto Alegre, 2007.

WERTZ, F. J. From everyday to psychological description: analysing the moments of a qualitative data analysis. Journal of Phenomenological Psychology, v. 14, n. 1, p. 197-241, 1983.

ZEICHNER, Kenneth M. Para além da divisão entre professor-pesquisador e pesquisador acadêmico In: GERALDI, C. M et al. (org.). Cartografia do trabalho docente: professor(a)pesquisador(a). Campinas: Mercado de Letras, 2007. p. 207-236. 